\title{
Uvodnik v tematski sklop
}

$\mathrm{V}$ zadnjem času smo priča povečanemu zanimanju za telo v vsakdanjem življenju in v naših vsakdanjih praksah, pa tudi v družboslovnih in humanističnih raziskavah in analizah. Pri tem zagotovo prednjačijo mediji, ki nas zasipavajo s podobami idealnih, zdravih, zagorelih, lepih, vitkih teles, ki so tako rekoč povprečnemu človeku/ženski nedosegljive. Ti isti mediji nas po eni strani posiljujejo z mnogimi dobrotami, recepti, hrano, po drugi pa s podobami vitkih teles, kar skorajda nujno vodi do frustracij ali pa do različnih oblik trpinčenj lastnega telesa. Ta se lahko kažejo v obliki občasnega hujšanja, anoreksije, bulimije, kompulzivnega prenajedanja, ortoreksije, bigoreksije (pretirane fizične aktivnosti) ipd. Če pa to ni učinkovito ali ni zadosti hitro, se je tudi za težave našlo zdravilo - oz. zdravnik - lepotni kirurg, ki nam izreže, zmanjša ali poveča tisto, kar hočemo oz. česar nočemo. Poraslo je tudi zanimanje za zdravo telo - ljudje hočejo, da bi bili videti zdravo, se počutiti zdravo, zato jejo zdravo hrano, se ukvarjajo s športom, skratka skrbijo za svoje telo.

Telo je hkrati del posameznika/posameznice, obenem pa je lahko njen/ njegov objekt oz. projekt - če se odločimo, ga bomo oblikovali tako, da bo krepko ali krhko, obilno ali skoraj shirano, lahko si okrepimo/povečamo ali zmanjšamo ta ali oni del, možnosti so stvar naše domišljije in časovno - finančnih možnosti. Ta interes je, kot je opozoril že Bourdieu (1984), najbolj prisoten pri t.i. novem srednjem razredu, najverjetneje se je v zadnjem času razširil tudi na druge sloje.

Telo pa ne predstavlja le stvar zanimanja posameznikov in posameznic ampak tudi oblasti oz. politike. Če pritrdimo Foucaultu, se je oblast pravzaprav vedno zanimala za telesa svojih podrejenih. Že davno tega so bila telesa predmet nadzorovanja in kaznovanja, telesne kazni so bile prve oblike kaznovanja neubogljivega ljudstva in za razliko od danes so bila ta kaznovanja vsem na ogled in v opozorilo. Zdi se, da oblast/politika teles ni nikoli izpustila iz svojega primeža, le da so se oblike nadzorovanja in kaznovanja spreminjale/spremenile - predvsem najbrž to velja za ženska telesa. 
Telo je bilo, je in bo predmet zanimanja različnih ved in polj. Čeprav je bilo videti, da si ga je najprej za ekskluzivno polje svojega delovanja privzela medicina, pa se z njim ukvarjajo (je predmet njihovega raziskovanja) tudi druge vede oz. znanstvene discipline od sociologije in antropologije, študijev spola, umetnostne zgodovine, literarne zgodovine in drugih. Večkrat ponovljena modrost, da nimamo svojega telesa, temveč smo telo, je v sodobnem družbosovju in humanistiki postala prežvečena puhlica. In prav zato, ker nas vabi v objem najbolj duhamornega vulgarnomaterialističnega redukcionizma, jo je vredno od časa do časa premisliti. Imeti telo ali biti telo? Frommovska dilema sploh ni na izbiro: človeštva si ni mogoče predstajati v breztelesnem ali - bognedaj! - raztelešenem stanju. Celotno človeštvo, ki edino ustvarja, posreduje, uporablja in preobrača simbole, skratka "simboli", če smeva uporabiti glagol, ki si ga je neuspešno zamislil Leslie White, ustvarja neskončne nize neopredmetenih zamisli, a nikakor ne more ustvariti enega samega simbola, torej predmeta, ki omogoča reprezentacijo, tako da ga postavimo na mesto nečesa drugega, ne da bi se za to pomučilo v potu svojega obraza. Še več, največje skrivnosti, kar si jih lahko zamislimo, izhajajo iz nizov telesih drž in sporočil, ki jih prevzemamo od drugih brez simboljenja.

Če smo še pred tremi desetletji govorili skorajda samo o strukturah (ne da bi dobro premislili paleto pomenov tega danes skorajda pozabljenega koncepta), pa pred desetletjem in pol o tekstih in njihovem »branju«, si danes ne moremo predstavljati humanistične razprave, ki ne bi umeščala razumevanja človeške sporočilnosti na raven neposrednih človeških dejavnosti. Pri tem v glavnem ne gre za obujanje pragmatizma, ki bi ga spodbujala prevlada anglosaške teoretske misli, niti za slepo sledenje vmes skorajda pozabljenim spoznanjem o telesnem ustroju človeških svetov Merleau-Pontyja, temveč za premik, v katerega nas sili soočanje z dogajanji $\mathrm{v}$ resničnem svetu, na katera se moramo ustrezno odzvati kot raziskovalci in raziskovalke.

Pričujoči tematski sklop revije Ars et Humnitas prinaša pestro paleto različnih pristopov in prikazov telesa v polju družboslovja in humanistike od teoretskih razprav v okviru post-fenomenološke sociologije telesa, tematiziranja telesa $\mathrm{v}$ odnosu do zdravja in plesa, pa vse do razprav o le- 
potnem idealu telesa $\mathrm{v}$ florentinskem slikarstvu, golote in spola $\mathrm{v}$ žanru akta ter pomena fotografij (ki predstavljajo zamrznjena telesa), s pomočjo katerih je mogoče odstirati osebne zgodovine.

Milica Antić Gaber

Rajko Muršič 